$1-1-1964$

\title{
Relative susceptibility of Appalachian hardwood species to spring frosts occurring after bud break
}

Earl H. Tryon

R. P. true

Follow this and additional works at: https://researchrepository.wvu.edu/ wv_agricultural_and_forestry_experiment_station_bulletins

\section{Digital Commons Citation}

Tryon, Earl H. and true, R. P., "Relative susceptibility of Appalachian hardwood species to spring frosts occurring after bud break" (1964). West Virginia Agricultural and Forestry Experiment Station Bulletins. 503.

https://researchrepository.wvu.edu/wv_agricultural_and_forestry_experiment_station_bulletins/468 @ WVU. It has been accepted for inclusion in West Virginia Agricultural and Forestry Experiment Station Bulletins by an authorized administrator of The Research Repository @ WVU. For more information, please contact ian.harmon@mail.wvu.edu. 
West Virginia University Libraries

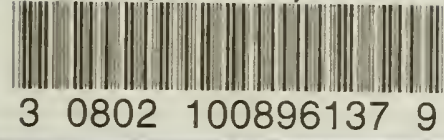


Digitized by the Internet Archive in 2010 with funding from Lyrasis Members and Sloan Foundation 


\section{AG.ENG LIBRARY WEST VIRGINIA UNIVERSTTY}

Relative Susceptibility of

Appalachian Hardwood Species

To

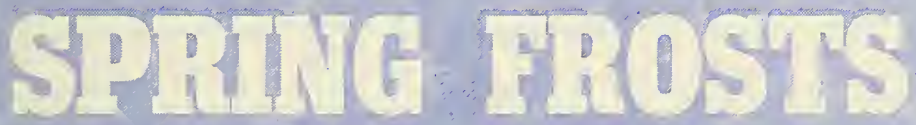

Occurring After Bud Break 


\section{THE AUTHORS}

The authors of Relative Susceptibility of Appalachian Hardwood Species to Spring Frosts Occurring After Bud Break are E. H. Tryon, Silviculturist in the Agricultural Experiment Station and Professor of Silviculture in the Division of Forestry, and R. P. True, Plant Pathologist in the Agricultural Experiment Station and Professor of Plant Pathology in the Department of Plant Pathology, Bacteriology, and Entomology.

West Virginia University Agricultural Experiment Station

College of Agriculture, Forestry, and Home Economics A. H. VanLandingian, Director Morgantown 


\section{Relative Susceptibility of Appalachian Hardwood Species to Spring Frosts Occurring After Bud Break}

E. H. TRYON and R. P. TRUE

ROSTS occur frequently in the Appalachian region, and spring frosts - which occur after growth has started are especially damaging to forest trees. Such frosts deform stems, reduce growth rate, and may kill the smaller reproduction. Although frost injury is widespread and recurs each year, the damage is often unnoticed or is observed months later without its true cause being recognized.

The Appalachian region's irregular topography provides many pockets for the accumulation of cold, heavy air. Such conditions are ideal for heavy spring frosts. Many of the susceptible species that comprise the region's mixed hardwood forests, such as yellow-poplar, ${ }^{1}$ frequent rich cove and bottomland soils where these frosts are common, severe, and very damaging.

Trees of all sizes may be damaged, but the reproduction and saplings are usually most severely injured. The period of establishment is therefore critical. Reproduction cuttings may be made to protect the young trees as well as to regenerate the next stand.

The primary purpose of this report is to describe the relative susceptibility of common hardwood species to damage by frost occurring after budbreak. ${ }^{2}$ In addition, factors involved in preparing a frost susceptibility rating of tree species are considered, and silvicultural practices which will help reduce damage are discussed.

\section{Types of Frosts}

A frost may be defined either as a deposit of condensed water vapor in solid form called hoarfrost, or as a condition existing when the tem-

${ }^{1}$ An index of technical names, arranged alphabetically by common name, may be found in the Appendix. Technical names follow Little, Albert L., 1953. Check list of native and naturalized trees of the United States. Forest Service. USDA Agricultural Handbook No. 41,472 pp.

${ }^{2}$ Excluded from specific consideration here are a number of injuries caused by freezing of intercalary portions of the stem, such as: frost cracks, frost shakes, frost cankers, winter sunscald, frost blister, and blister shake, all of which also affect hardwood species. 
perature is $32^{\circ} \mathrm{F}$ or lower without the formation of hoarfrost (Trewartha 1954). The latter definition is the one more commonly used today in referring to frosts in relation to forests. In this report, a frost will be considered to occur after the temperature has dropped below freezing causing some damage to the buds or foliage of one or more species, soon after growth has begun.

The terms "killing frost," "destructive frost," and "freeze" all denote frosts which cause severe damage (Blair 1942, Geiger 1950). Black frost and black freeze sometimes indicate severe frosts which kill the new growth so quickly that it soon wilts and darkens. A late frost, one which occurs in the spring or early summer, is distinguished from early frost, which occurs in the fall.

Two recognized types of frosts are advective frosts and radiation frosts. Advective frosts, called freezes, result when the horizontal movement of a cold air mass brings freezing temperatures into an area. Such air masses may cover thousands of square miles. Within such an air mass the vertical temperature-lapse rate is usually normal, with temperature decreasing with increasing altitude. The degree of foliage damage is quite uniform within belts of similar elevations, and severity of damage may increase with elevation (Tryon and True 1962).

A radiation frost results from a temperature inversion at the surface of the earth. This comes about when the earth loses heat through longwave radiation and its surface becomes colder than the adjacent air. The air layer next to the earth is cooled by contact with the earth's cold surface and becomes cooler than the air immediately above, thus creating a temperature inversion near the ground. The depth of such an inversion may vary from a few inches to several hundred feet. The cooler air near the ground has a greater density than the warmer air at the top of the inversion and is stable. Consequently it will remain stationary as long as the inversion exists unless the topography is such that gravity causes the heavier air to move downhill. Such movement of the cooler. heary surface air can deepen the cold air layers in hollows or bottomland. Areas near the brow of a hill will become warmer as the cold air drains away and is replaced by warmer air. Thus, radiation frosts occur in local depressions and on lower slopes.

Where radiation frosts occur in low areas, a considerable difference in temperatures near the ground may occur between the top and the bottom of a slope. An extreme example of this was reported in California when a frost occurred at the bottom of a slope having a difference in elevation of over 250 feet. Near the top the temperature was $49^{\circ} \mathrm{F}$, at the middle it was about $45^{\circ} \mathrm{F}$, but at the bottom a low of $21^{\circ} \mathrm{F}$ was recorded (Young 1920). 
Radiation frosts are more frequent than advective frosts. Biel (1961) stated that most frosts in California are due to radiation, but east of the Rocky Mountains the frequency of advective frosts is rather high, with New Jersey having 30 per cent of its frosts advective. The authors' recent observations indicate that radiation frosts make up a much higher proportion of the frosts causing observed damage in West Virginia than was indicated by Biel for most of the East. The predominance of radiation frosts in such mountainous areas should be expected, and West Virginia provides many small bottomland areas and valleys into which cold air drains. Advective frosts commonly occur in early spring and late fall, whereas radiation frosts usually occur first in the fall, last in the spring, and throughout the season of frost incidence. Information from the Weather Bureau Agricultural Service Office at Kearneysville, West Virginia, indicates that most frosts occurring in the State after April 20 are of the radiation type. ${ }^{3}$

A summary of these two types of frost as related to damage is presented in Table 1.

\section{Table 1. Summary of Frost Types and Damage to Forests}

\begin{tabular}{|c|c|c|}
\hline Characteristic & Advective Frost & Radiation Frost \\
\hline Cause & $\begin{array}{l}\text { Horizontal movement of cold air } \\
\text { mass into a warmer area. }\end{array}$ & $\begin{array}{l}\text { Cooling of ground and adjacent } \\
\text { air through loss of heat from } \\
\text { long-wave terrestrial radiation. }\end{array}$ \\
\hline $\begin{array}{l}\text { Condition } \\
\text { of } \\
\text { atmosphere }\end{array}$ & $\begin{array}{l}\text { Windy, overcast, often with } \\
\text { precipitation-including snow. }\end{array}$ & $\begin{array}{l}\text { Clear with still air, cloudless } \\
\text { sky. }\end{array}$ \\
\hline $\begin{array}{c}\text { Area } \\
\text { involved }\end{array}$ & $\begin{array}{l}\text { Large, may be hundreds of } \\
\text { square miles, and may be con- } \\
\text { fined to mountain tops. }\end{array}$ & $\begin{array}{l}\text { Small, often only valley bottoms } \\
\text { and lower slopes. }\end{array}$ \\
\hline Severity & $\begin{array}{l}\text { Usually causes heavy damage if } \\
\text { buds have broken. }\end{array}$ & $\begin{array}{l}\text { Variable. Damage may be very } \\
\text { light to heavy. }\end{array}$ \\
\hline $\begin{array}{l}\text { Elevation } \\
\text { and damage }\end{array}$ & $\begin{array}{l}\text { Damage may become heavier } \\
\text { with increase in elevation. }\end{array}$ & $\begin{array}{l}\text { Damage usually greater on lower } \\
\text { slopes and in valleys. }\end{array}$ \\
\hline Uniformity & $\begin{array}{l}\text { Degree of damage uniform with- } \\
\text { in same elevation belt. }\end{array}$ & $\begin{array}{l}\text { Degree of damage spotty from } \\
\text { area to area, and even within } \\
\text { same locality. }\end{array}$ \\
\hline Frequency & Less common. & More common. \\
\hline $\begin{array}{c}\text { Time of } \\
\text { occurrence }\end{array}$ & Early in spring; late in fall. & $\begin{array}{l}\text { First in fall; last in spring, and } \\
\text { throughout frost danger period. }\end{array}$ \\
\hline
\end{tabular}

${ }^{3}$ Personal correspondence from Walter L. Stirm, Advisory Agricultural Meteorologist. 


\section{Frost Susceptibility Ratings}

Considerable variation exists among reports of frost susceptibility of tree species. Some reasons for reported differences have been revealed by our own observations on the susceptibility of hardwood species to frosts in different localities and on different occasions.

Factors which appear to contribute to differences in the frost susceptibility ratings of a species are:

\section{(a). Condition of Buds or Developing Leaves:}

A spring frost commonly causes damage to a tree whose buds have started to swell or open or whose foliage is already developing. Unless the exact stage of bud development when the frost occurs is known, the resistance of the foliage of a species to frost damage cannot be evaluated accurately. For example, the newly developing foliage of black locust is very susceptible to frost, but here the buds of the locust open somewhat later than those of associated forest species. Therefore, an early spring frost may not affect the locust but may damage the foliage of more resistant species. Baker (1950), Boyce (1961), Ohweiler (1912), and Peace (1962) have commented on differences in species in date of bud break.

The age of the developing leaf also seems to affect resistance to frost damage. Young leaves seem more susceptible than older leaves of the same species.

\section{(b). Type of Damage Used to Measure Relative Susceptibility:}

The effect of late frosts on new leaves and shoots is commonly used to rate species susceptibility. However, other responses to frost such as effect on flowers and radial increment (Tryon and True 1964) and formation of frost rings might be used. The same susceptibility rating of species would not be expected if frost ring occurrence rather than foliage damage were used as a criterion. The thickness of bark, which is an inherent characteristic as well as a function of bole diameter, can be a factor influencing the presence or absence of frost rings (Rhoads 1923). Thick bark could prevent the formation of a frost ring in the bole of a tree whose foliage might be killed. Also, growth in the lower bole may be initiated later than in the buds. Thus by using foliage damage as the criterion, a tree or species could be evaluated susceptible to frost although it might be classed as resistant if frost rings were used.

\section{(c). Severity of Frost:}

The severity of a frost is a major factor affecting the frost susceptibility rating of tree species, especially if based on a 
single frost. An extremely severe late frost could kill all the new foliage on all species then in leaf, making them all appear equally susceptible. However, a very light frost may do but slight damage to only one or two species. In this latter instance, most species would be rated frost hardy.

\section{(d). Type of Frost:}

Advective frosts at comparable elevations cause uniform damage to trees. Local topographic differences, degree of stand opening, or protection received from overstory canopies exert little influence. Radiation frosts, however, are greatly affected by such local situations. Border trees of openings in the forest and along wood roads may be damaged by these frosts as may the exposed reproduction within the openings. Neighboring trees forming a closed canopy and the reproduction beneath, however, may be undamaged. This difference in damage between the two localities results from temperature differences.

Damage resulting from an advective frost provides a much more uniform and valid criterion for a frost susceptibility rating than does that from a radiation frost.

\section{(e). Comparisons of Susceptibility of Exotic with Native Species Grown in Same Location:}

Susceptibility ratings have been made in areas containing both native and exotic species (Blair 1946, Ohweiler 1912, and Ramsey 1871-72). Such information might be helpful for the specific condition but is of little value in a general species rating. Date of bud break and general conditions of exotics where tested may differ widely from those existing in their native habitat. Also, species native to the general area, but planted off site from the standpoint of climate, may show an abnormal response to frosts (Nienstadt 1958, Peace 1962).

Other factors influencing apparent sensitivity include genetic variation, as some individuals within the same species appear to be more resistant than others to frost (Blair 1946, Boyce 1961). Variation in degree of frost damage at different positions on the tree also occurs (Pomerleau and Ray 1957). Different parts of the tree may be affected differently, as, for example, when a temperature inversion of a shallow layer of air near the ground causes frost damage to the lower part of a tree although the upper portion is undamaged.

Thus several factors influence the occurrence and severity of frosts, and various conditions of the tree may influence the incidence or degree of damage. With so many significant variables determining the occurrences of frosts and the degree of damage, it is understandable that considerable care must be taken in preparing an accurate frost susceptibility rating for species in any area. 


\section{Susceptibility of Appalachian Hardwood Species}

A frost-susceptibility rating of Appalachian hardwoods was prepared following examinations of tree species in 12 localities in which radiation and advective type frosts occurred during the spring seasons of 1961 and 1963. These localities were in northern and east-central West Virginia. The ratings in all instances were based on the degree of damage to the newly formed leaves and shoots following late frosts.

An examination was made of the damage and stage of foliage development of the trees, and the conditions were recorded by species. The amount of damage ranged from complete kill of all leaves to a slight kill or curling of the leaf margins of a few leaves per tree. The degree of damage was listed as Killed, Heavy, Medium, Light, Very Light, or None and was determined subjectively.

The susceptibility ratings are presented in Table 2. It is evident that considerable variation exists in susceptibility to late frosts among these hardwoods, including the more valuable species. Within the limits of the study, black cherry was definitely most resistant to late frost damage, and was followed by sugar maple and American basswood which were slightly less resistant. Yellow-poplar, black walnut, and American beech were among the species most susceptible to frost damage, with the oaks being slightly less susceptible. Considerable tree-to-tree variation in frost susceptibility was found for white ash and yellow birch. Although these species are rated as moderately susceptible, individual

\section{Table 2. Susceptibility of Appalachian Hardwood Species to Frost Daniage}

\begin{tabular}{|c|c|c|c|}
\hline $\begin{array}{c}\text { Highly } \\
\text { SuSCEPTIBLE }^{*}\end{array}$ & $\begin{array}{l}\text { MODERATELY } \\
\text { SUSCEPTIBLE }\end{array}$ & $\begin{array}{c}\text { LESS } \\
\text { SuSCEPTIBLE }\end{array}$ & $\begin{array}{c}\text { LEAST } \\
\text { Susceptible }\end{array}$ \\
\hline $\begin{array}{l}\text { Sassafras } \\
\text { American sycamore } \\
\text { Black locust } \\
\text { American beech } \\
\text { Cucumbertree } \\
\text { Yellow-poplar } \\
\text { Hickory spp. } \\
\text { Black walnut } \\
\text { Butternut }\end{array}$ & $\begin{array}{l}\text { Fraser magnolia } \\
\text { White ash } \\
\text { American chestnut } \\
\text { White oak } \\
\text { Scarlet oak } \\
\text { Chestnut oak } \\
\text { Northern red oak } \\
\text { Yellow birch } \\
\text { Black birch } \\
\text { Bo }\end{array}$ & $\begin{array}{l}\text { Smooth alder } \\
\text { Serviceberry } \\
\text { Witch-hazel } \\
\text { Striped maple } \\
\text { Fire cherry } \\
\text { Red maple }\end{array}$ & $\begin{array}{l}\text { Slippery elm } \\
\text { Willow } \\
\text { Flowering } \\
\quad \text { dogwood } \\
\text { Hawthorn } \\
\text { American basswood } \\
\text { Sugar maple } \\
\text { Black cherry }\end{array}$ \\
\hline
\end{tabular}

\footnotetext{
-The most susceptible species are at the top and the least susceptible are at the bottom within each susceptibility class.

- Based on few observations.

†Considerable variation in degree of damage.
} 
trees varied from resistant to highly susceptible. Possibly genetic differences of response to frost damage are greater in these two species than in the others. Differences may exist among individuals within a species in actual resistance of the young leaf and shoot to cold, and also in date of bud break.

The wide range of species susceptibility to late frost damage found among the valuable hardwood species indicates that consideration should be given to the selection of resistant species when stands are being regenerated in locations where frost pockets occur.

\section{General Rating of Genera and Species By American and European Writers}

An attempt was made to learn whether the frost susceptibility ratings of species or genera from widely separated areas were generally in agreement. To accomplish this, the works of authors who have made frost susceptibility ratings or listed degree of damage by species in this and other countries were assembled and compared. The damage to newly developing foliage, leaves, and shoots by late frosts was the criterion used. The species and genera included in this bulletin were the ones selected for comparison. Also, an effort was made to include, from each study, only those species or genera which were native to the area where the study was made.

The difficulties encountered in evaluating the frost susceptibility of species from a single frost occurrence or for a single locality have already been discussed, and combining the data of several authors further reduces the accuracy because each author presented the data in a different fashion. Also, in some publications genera rather than species are compared. As all species within a genus are not necessarily affected to the same degree by frost, the reliability becomes less certain. In spite of these obvious shortcomings, the combined results of eight investigators are presented in Table 3. The numbers in parentheses after each species indicate that the authors cited placed the susceptibility of that species as listed by the column heading. Listings of a different frost susceptibility rating by the different authors are not indicated. Also, not all authors evaluated all species.

The agreement of authors as to the ratings of species and genera was surprisingly close. Cherry, willow, and maple were among the more resistant. Ash, beech, sycamore, walnut, and yellow-poplar were highly susceptible to frost damage. The oaks were rated moderately susceptible although one study listed them as highly susceptible. 
Table 3. Susceptibility of Genera Aid Species of Hardwoods TO Foliage DAitage by LAtE Frosts

\begin{tabular}{|c|c|c|c|}
\hline $\begin{array}{c}\text { Highly } \\
\text { SusCEPTIBLE }\end{array}$ & $\begin{array}{l}\text { MODERATELY } \\
\text { SCSCEPTIBLE }\end{array}$ & $\begin{array}{c}\text { Less } \\
\text { SusCEPTIBLE }\end{array}$ & $\begin{array}{c}\text { LEAST } \\
\text { SUSCEPTIBLE }\end{array}$ \\
\hline $\begin{array}{l}\text { American chestnut }(4,6) \div \\
\text { Ash }(2,4,5,7,8) \\
\text { Beech }(2,4,6,7,8) \\
\text { Black locust }(4,8) \\
\text { Sassafras }(5,8) \\
\text { Sycamore }(1,3,4,8) \\
\text { Walnut }(4,7,8) \\
\text { Yellow-poplar }(3,8)\end{array}$ & $\begin{array}{l}\text { Magnolia }(5) \\
\text { Oak }(7,8)\end{array}$ & $\begin{array}{l}\text { Basswood }(4,5) \\
\text { Maple }(2,4,5,7,8)\end{array}$ & $\begin{array}{l}\text { Birch }(1.2,3) \\
\text { Cherry }(2,6,8) \\
\text { Elm }(4,8) \\
\text { Hawthorn }(4,8) \\
\text { Willow }(1,2,4,8)\end{array}$ \\
\hline
\end{tabular}

1. Blair, J. H. 1946

2. Cary, A. 1903

3. Murray, J.S. 1955

4. Neger, F. W. 1924
5. Ohlweiler, WV. WV. 1912

6. Ramsey, J. 1871-72

7. Schadelin, IV. 1920

8. Present paper

"The genera and species are not ranked within a column, but listed alphabetically.

$\div$ The numbers following a species or genus indicate that the authors of similar number gave the species such a susceptibility rating. The complete reference, by authors, is given under Literature Cited.

\section{Application of Frost Susceptibility Information To Forestry Practice}

The influence of many site factors on the species as well as the prospective value of the species should be considered wherever forest management is practiced. In selecting species to be raised, one must be certain that the climate is favorable, that soil moisture and fertility are adequate. and that known serious diseases are not present or are subject to control. When regenerating species, the light requirements and ability to withstand competition generally require primary consideration. In certain areas a specific site factor, perhaps generally of secondary importance. may be dominant in its effect on the forest stand and deserves first consideration. Frost is such a site factor. The following discussion pertains especially to those areas where frosts are frequent, severe, and damage tree species.

The relative susceptibility of tree species to frost damage should be considered when forest stands are being regenerated where frosts are frequent. Any species is subject to injury to new leaves and shoots if the frost is sufficiently severe. The new or current season's growth may be damaged on trees of all sizes. but reproduction is most affected. Damaged reproduction often produces trees with crooked single stems or multiple stems. Susceptible seedlings struck by repeated frosts may be killed. Fortunately the hardwoods lave considerable ability to recover by sending out new shoots below the damaged portions. For example, oak 
seedlings a few weeks old send out twin sprouts after the original shoot is killed back to ground line. Older oak seedlings also sprout from below the frost-damaged tips. Where frosts constitute a threat, the more resistant species, such as sugar maple and black cherry, should be favored over the more susceptible yellow-poplar, black walnut, and even oak species.

\section{Advective Frosts in Relation to Forestry Practices}

Little can be done through silvicultural manipulation of the stand to reduce injury to understory stems from an advective frost. Possibly a canopy, especially of conifers, might give some protection to the understory if the advective frost were light. A severe advective frost, locally called a black freeze, which occurred in May, 1961 in the mountains of central and southern West Virginia caused considerable damage to a hardwood stand, and here the canopy provided no protection to the understory vegetation. It seems doubtful if a partial canopy left as a result of a silvicultural cutting would give adequate protection.

\section{Radiation Frosts in Relation to Forestry Practices}

Damage to understory stems, including newly established regeneration, by radiation frosts may often be reduced or eliminated by proper silvicultural treatment of the stand. Because radiation frosts result from a temperature inversion and may be accompanied by the flow of heavy, cold air into valleys and depressions, the air temperature is coldest at the ground line, where frost damage tends to be greatest. As a consequence, seedlings and portions of trees near the ground are sometimes more seriously damaged than the upper portions of larger individuals. This situation may give the erroneous impression that the new leaves and shoots of the older, larger individuals have greater frost resistance than those of smaller seedlings. The actual difference is caused by the temperatures at different levels, rather than by the age of the individuals.

Regenerating hardwood stands by natural methods in areas subject to repeated radiation frosts requires that a silvicultural method be used which leaves at least a partial canopy following the cutting. The reproduction favored should be composed of the most frost resistant species, if possible. The denser the canopy, the better the protection from radiation frosts. Such methods as single tree selection, group selection, and shelterwood meet the requirement of providing a canopy following the cutting. The use of the single tree selection method is considered impractical under many circumstances, but might find a place in regenerating stands in those limited areas where frosts are common and damage is severe. If the single tree selection method is employed, species which are 
tolerant ${ }^{4}$ as well as frost resistant should be favored. This would include such species as sugar maple, red maple, and basswood.

When using the group selection method, relatively small openings are preferred. Those openings having diameters less than 11\% times the heights of border trees have been reported to give frost protection, whereas larger openings did not (Geiger 1950). Based on such a recommendation, and with border trees 80 feet tall, the opening should not exceed one-quarter acre.

The shelterwood method, when used to protect the regeneration from frost, should require at least three cuttings over a 15 - to 20-year period. The first cutting should be light, allowing as much of the canopy to remain as possible. Twenty to thirty per cent of the canopy should be sufficient to remove in the first cut. The next two cuts could be approximately equal, each taking about half of the merchantable trees remaining after the first cut.

The group selection and shelterwood methods as described for use in the frost-damage areas will tend to favor tolerant and semi-tolerant species, althongh this will be temporary for the latter method. Actually, many of the species studied (and listed in Table 2) could be regenerated by either method, provided cleanings were made as needed. The oaks and hickories should be capable of being regenerated and grown by either method. By using the group selection method, the maples, basswood, and yellow birch could perhaps be better managed. Black cherry deserves special consideration as a hardwood species to favor in frost areas. It is one of the most frost-resistant species, but is intolerant. Fortunately, it displays considerable tolerance when young, and should be suitable to management by using the shelterwood method.

Regenerating hardwood stands by sprouts appears to be a poor procedure in areas where frosts occur and this should be avoided. Observations made during the present study indicated that young sprouts are more heavily damaged by frosts than stock of seedling origin.

Forest plantings in the Appalachians are established mainly on old fields where no overhead protection from frost is provided; consequently, damage may be expected to occur in bottoms and lower slopes where frosts are common. Planting frost-resistant species appears to be the best method of reforesting such areas quickly, but this may not always be practical. Conifers generally are preferred over hardwoods for planting because their establishment is more often successful and their growth is better. Conifers tend to be less damaged by frost than the hardwoods because their foliage is less susceptible or their bud break is

${ }^{4} \mathrm{~A}$ tolerant species is one which has a relatively high ability, as compared with other native species, to grow in the shade beneath a canopy of larger trees. 
later, so they are recommended for planting on sites where the frosts occur. The more resistant conifers, such as certain pine species, should oe preferred. Eastern white pine should be one of the better species for olanting, particularly at the higher elevations where frost is a problem. It is capable of growing well on the imperfectly drained soils common o many bottomland areas where frosts occur.

In addition to choosing frost-resistant species, there is the possibility of developing, within a species, clones which exhibit an especially high degree of frost resistance for regenerating high-risk areas. With the derelopment of a hardwood tree improvement program, it appears feasible o include frost resistance as one of the desirable characteristics.

In conclusion, the more resistant species should be chosen when possible in regenerating areas by either natural or artificial means, and he group selection and shelterwood methods are recommended for rezenerating forest stands naturally where frost is a problem.

\section{literature Cited}

3aker, Frederick S. 1950. Principles of silviculture. McGraw-Hill Book Company, Inc. New York.

3iel, E. R. 1961. Microclimate, bioclimatology and notes on comparative dynamic climatology. American Scientist 49:326-357.

3lair, James Hunter. 1946. Frost damage to woodlands on Blairguhan Estate in April 1945. Scottish For. Jour. 60:38-43.

3lair, Thomas A. 1942. Weather elements. Prentice-Hall, Inc. New York.

3oyce, J. S. 1961. Forest pathology, 3rd Ed. McGraw-Hill Book Company, Inc. New York.

Cary, Austin. 1903. Note on relative frost hardiness. Forestry Quart. 2:22-23.

Geiger, Rudolf. 1950. The climate near the ground. A translation by M. N. Stewart and others. Harvard University Press. Cambridge.

Hemenway, Ansel F. 1926. Late frost injury to some trees in central Kentucky. Amer. Jour. Bot. 13:364-366.

Murray, J. S. 1955. An exceptional frost in East Anglia. Quart. Jour. For. 49:120-125.

Veger, F. W. 1918. Die Krankheiten unserer Waldbaume. Ferdinand Enke, Stuttgart.

vienstadt, H. 1958. Height growth is indicative of the relative frost resistance of hemlock seed sources. Lake St. For. Exp. Sta. Tech. Note 525. 2 pp.

Ohlweiler, W. W. 1912. Relation between the density of cell saps and the freezing point of leaves. Twenty-Third Annual Report, Missouri Bot. Garden. 101-131.

Peace, T. R. 1962. Pathology of trees and shrubs. Clarendon Press, Oxford.

?omerleau, Rene and R. G. Ray. 1957. Occurrence and effects of summer frost in a conifer plantation. Dept. of Northern Affairs and National Resources. For. Research Div. Tech. Note 51. 15 pp. 


tesing

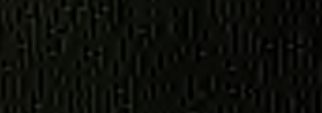

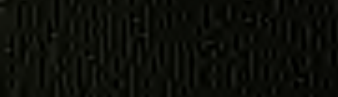

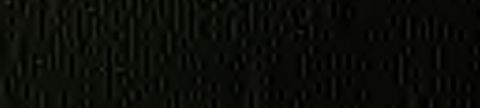

p

(it.

$\sin$

sthing

IIIPI)

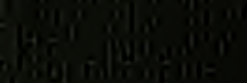

ing

6.7.

$\operatorname{in}^{2}=10$

$(i, 1)$

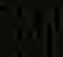

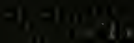

年

HII

U10

ching

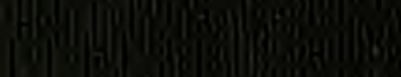

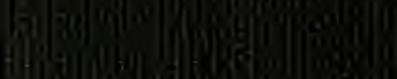

1.

dench

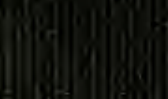

